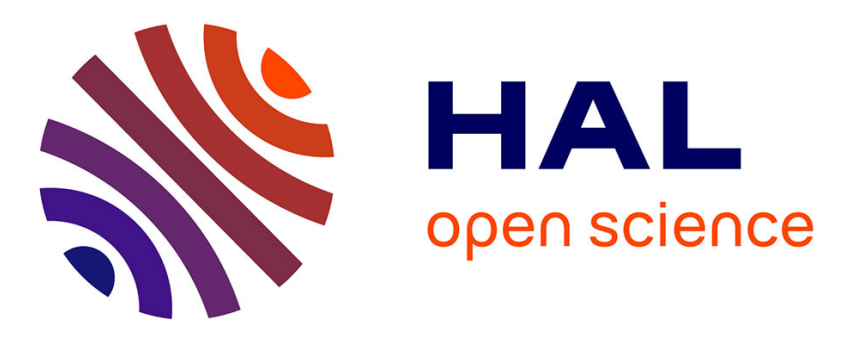

\title{
Amperometric cytochrome c3-based biosensor for chromate determination
}

Caroline Michel, Fabienne Battaglia-Brunet, Canh Tran-Minh, Mireille Bruschi, Ioannis Ignatiadis

\section{- To cite this version:}

Caroline Michel, Fabienne Battaglia-Brunet, Canh Tran-Minh, Mireille Bruschi, Ioannis Ignatiadis. Amperometric cytochrome c3-based biosensor for chromate determination. Biosensors and Bioelectronics, 2003, 19 (4), pp.345-352. 10.1016/S0956-5663(03)00191-X . emse-00519585

\section{HAL Id: emse-00519585 https://hal-emse.ccsd.cnrs.fr/emse-00519585}

Submitted on 21 Sep 2010

HAL is a multi-disciplinary open access archive for the deposit and dissemination of scientific research documents, whether they are published or not. The documents may come from teaching and research institutions in France or abroad, or from public or private research centers.
L'archive ouverte pluridisciplinaire HAL, est destinée au dépôt et à la diffusion de documents scientifiques de niveau recherche, publiés ou non, émanant des établissements d'enseignement et de recherche français ou étrangers, des laboratoires publics ou privés. 


\title{
Amperometric cytochrome $c_{3}$-based biosensor for chromate determination
}

\author{
Michel CAROLine(1), BATtaglia-BRUNET FABIENNE(1), TRAN-MinH CANH(2), BRUSCHI \\ MIREILLE $^{(3)}$, IGNATIADIS IOANNIS ${ }^{(1) *}$
}

(1) BRGM, Service Environnement Industriel et Procédés Innovants, Unité Biotechnologies, 3 Avenue Claude Guillemin, BP 6009, 4506o, Orléans Cedex 02, France

(2) Ecole Nationale Supérieure des Mines de Saint Etienne, Centre SPIN ; Département PMMC ; 158 Cours Fauriel ; 42023 Saint-Étienne Cedex 2, France

(3) CNRS, IBSM, Laboratoire de Bioénergétique et Ingénierie des Protéines, 31 chemin Joseph Aiguier, 13402, Marseille Cedex 20, France

\begin{abstract}
The chromate reductase activity of cytochrome $c_{3}$ (Cyt $c_{3}, M_{\mathrm{r}} 13$ ooo), isolated from the sulfate-reducing bacterium Desulfomicrobium norvegicum, was used to develop an amperometric biosensor to measure chromate $\left(\mathrm{CrO}_{4}{ }^{2-}\right)$ bioavailability. The performance of various biosensor configurations for qualitative and quantitative determination of $\mathrm{Cr}(\mathrm{VI})$ was studied. Biosensor properties depend on the technique used to immobilize the enzyme on the electrode (glassy carbon electrode). Immobilization of Cyt $c_{3}$ by entrapment in poly 3,4ethylenedioxythiophene films denatured the enzyme, while application of an adsorption technique did not affect enzyme activity but the detection range was limited. The best results were obtained with dialysis membranes, which allowed the determination of $\mathrm{Cr}(\mathrm{VI})$ from 0.20 to $6.84 \mathrm{mg} \mathrm{l}^{-1}\left(3.85^{-132} \mu \mathrm{M}\right)$ with a sensitivity of $35 \mathrm{nA} \mathrm{mg}^{-1} \mathrm{l}\left(1.82 \mathrm{nA} \mu \mathrm{M}^{-1}\right)$. No interference was observed with $\mathrm{As}(\mathrm{V}), \mathrm{As}(\mathrm{III})$ and Fe(III). Only a small amount of Cyt $\mathrm{c}_{3}$ (372 ng of protein) was needed for this biosensor.
\end{abstract}

Keywords:

Enzymatic sensor; Polyheme cytochrome $c_{3}$; Chromate quantification; Sulfate-reducing bacteria; Environmental biosensor; Chronoamperometry

\section{Introduction}

Most heavy metals and metalloids (HMM) are toxic for plants, animals and humans. Chromium, which can contaminate soils, ground- and surface waters, is one of the major environmental pollutants. The toxicity of chromium, like other HMM, depends on its oxidation state and bioavailability. For example, $\mathrm{Cr}(\mathrm{VI})$ is a highly toxic and soluble oxyanion, whereas $\mathrm{Cr}$ (III) is cationic, less toxic and less mobile because it tends to form insoluble hydroxides. The assessment of HMM bioavailability with analytical methods such as sequential extraction and mathematical modeling is difficult, expensive and time-consuming. The redox speciation of chromium can be accomplished by separate preconcentration of $\mathrm{Cr}(\mathrm{III})$ and $\mathrm{Cr}(\mathrm{VI})$ fractions using chelating resins, coprecipitation, ion chromatography, and solvent extraction, but such procedures are obviously complicated. The colorimetric analytical method at $543 \mathrm{~nm}$ for chromium using diphenylcarbazide as reagent is known to be selective for $\mathrm{Cr}(\mathrm{VI})$ but not $\mathrm{Cr}(\mathrm{III})$. However, 72 foreign ions are known to interfere by clouding or

*Auteur à qui la correspondance devait être adressée : i.ignatiadis@brgm.fr 
discoloring the sample. The measuring range of this method is $0.05^{-2.00 ~} \mathrm{mg} \mathrm{l}-1 \mathrm{Cr}$ or $0.11-$ $4.46 \mathrm{mg} \mathrm{l}-1 \mathrm{CrO} 42-$ (Kit MERCK spectroquant ${ }^{\circledR}$ 1.14552.0001). Cr(III) can be indirectly determined by analyzing the total chromium (in the form of $\mathrm{Cr}(\mathrm{VI})$ ) after high acidification and oxidation of the solution that leads to $\mathrm{Cr}$ (III) oxidation in $\mathrm{Cr}(\mathrm{VI})$. Biosensors, however, in addition to their specificity, enable rapid, quantitative and in situ measurement of the metallic derivatives that interact with the biomaterial.

Several studies have shown that it is possible to make biosensors to quantify metals with genetically engineered microorganisms (D'Souza, 2001). Recombinant luminescent microorganisms such as Alcaligenes eutrophus (Peitzsch et al., 1998) and Saccharomyces cerevisiae (Lehmann et al., 2000) have been used to determine chromium (Peitzsch et al., 1998), cadmium, zinc, mercury and chromium (Ivask et al., 2002), arsenic and antimony (Ramanathan et al., 1997), cadmium and lead (Tauriainen et al., 1998). Other microorganisms, such as sulfate-reducing bacteria (Michel et al., 2001 and Tebo and Obraztsova, 1998), Enterobacter cloacae (Rege et al., 1997), and Deinococcus radiodurans (Fredrickson et al., 2000), are able to reduce $\mathrm{Cr}(\mathrm{VI})$ into $\mathrm{Cr}(\mathrm{III})$ and could, therefore, also be used in biosensors to differentiate between $\mathrm{Cr}(\mathrm{VI})$ and $\mathrm{Cr}(\mathrm{III})$. Engineered microorganism-based biosensors are able to detect low metal concentrations, but these whole-cell biosensors have several disadvantages: (1) long induction period (1-2 h before the signal is detected), (2) low specificity (detection of other metals) and (3) interference of other physiological metabolites (sulfate metabolism, metal oxidation-reduction) (Peitzsch et al., 1998, Tauriainen et al., 1998 and Cai and Dubow, 1997). These drawbacks can be avoided with enzymatic biosensors.

Enzymatic sensors for metal detection have already been described (Kormos and Lengauer, 2000 and Krawczynski vel Krawczyk et al., 2000). Potentiometric urease-based sensors sensitive to metals have been developed since some metals are urease inhibitors. Indirect detection of metals such as $\mathrm{Pb}^{2+}, \mathrm{Fe}^{2+}, \mathrm{Sn}^{2+}, \mathrm{Zn}^{2+}$ and $\mathrm{Hg}^{2+}$ has been achieved by reduction of the biosensor response to urea. Other proteins such as those involved in metal resistance mechanisms could be used to develop biosensors for direct detection of metals. For example, ChrA, which is involved in chromate resistance, can discriminate between $\mathrm{Cr}$ (VI) and $\mathrm{Cr}$ (III) (Cervantes et al., 2001). Several bacterial redox proteins that have metal-redox properties could also be of interest. For example, cytochromes $c_{3}$ and hydrogenases from sulfate- and sulfur-reducing bacteria (Battaglia-Brunet et al., 2002a and Chardin et al., 2002) have bioremediation properties because they can reduce various metals such as $\mathrm{U}(\mathrm{V})$ and $\mathrm{Cr}(\mathrm{VI})$ (Assfalg et al., 2002, Lojou et al., 1998, Lovley and Phillips, 1994 and Michel et al., 2001). While most hydrogenases are sensitive towards oxygen (Vignais et al., 2001), cytochromes c3 are not affected by oxygen, temperature, $\mathrm{pH}$, denaturing agents or ageing (Bianco et al., 1986 and Florens et al., 1995). They also have a good Cr(VI)-reductase activity (Lojou et al., 1998, Lovley and Phillips, 1994 and Michel et al., 2001). Cytochromes c3 are multiheme redox proteins with very negative redox potentials and are involved in the respiratory metabolism of sulfate- and sulfur-reducing bacteria (Bruschi, 1981 and Haser et al., 1979). They are, therefore, well suited for the development of enzymatic biosensors for $\mathrm{Cr}(\mathrm{VI})$ quantification. This type of biosensor could be of great interest for measuring $\mathrm{Cr}(\mathrm{VI})$ concentrations in surface or ground waters polluted by chromate (tannery effluents, chromium plating effluents, etc.) and assessing the efficiency of water (bio)treatment processes such as bioreactors.

We developed an amperometric biosensor to measure $\mathrm{Cr}(\mathrm{VI})$ bioavailability using cytochrome $\mathrm{c}_{3}$ from Desulfomicrobium norvegicum, a sulfate-reducing bacterium. Various techniques to immobilize the enzyme on the working electrode were tested by applying cyclic voltametry. Biosensor parameters such as sensitivity, specificity, linearity and detection limit were studied using chronoamperometry. 


\section{Materials and methods}

\section{II.1. Purification of Cyt $\mathrm{c}_{3}$}

Cyt $\mathrm{c}_{3}\left(M_{\mathrm{r}} 13\right.$ ooo) from Desulfomicrobium norvegicum (DSM 1741) was purified as described by (Bruschi et al., 1977). Various concentrations of purified cytochrome $c_{3}(2.85,14.3,28.5$, $47.5,60,71.25$ and $114 \mu \mathrm{M}$ in water) were used to optimize the biosensor response to $\mathrm{Cr}(\mathrm{VI})$.

\section{II.2. Immobilization of $\mathrm{Cyt}_{3}$ on the working electrode}

Four methods were tested to immobilize the enzyme on the working glassy carbon electrode (GCE):

a Entrapment with a dialysis membrane (Haladjian et al., 1994). A Spectra/Por ${ }^{\circledR}$ regenerated cellulose dialysis membrane (6-8.000 MWCO) was used to maintain a 2 $\mu \mathrm{l} \mathrm{Cyt} \mathrm{c}_{3}$ solution in contact with the electrode.

b Adsorption: $2 \mu$ of enzyme solution were deposited on the electrode and aerated for $30 \mathrm{~min}$.

c Entrapment of $5 \mu \mathrm{l}$ of a Cyt $c_{3}$ sample with cellulose nitrate filters (Sartorius AG (Goettingen, Germany), porosity 0.01-0.1 $\mu \mathrm{m}$ ).

d Entrapment in poly 3,4-ethylenedioxythiophene (PEDT) films obtained by electropolymerization (at $+1400 \mathrm{mV} / \mathrm{SCE}$ for $10 \mathrm{~s}$ ) of a $10 \mu \mathrm{l}$ solution containing Cyt $\mathrm{c}_{3}$ (10\% v/v) and PEDT (10 mM).

\section{II.3. Apparatus}

Cyclic voltametry and chronoamperometry techniques were done with an EG\&G 273A potentiostat controlled by a microcomputer with an EG\&G M270 software program (Princeton Applied Research, Oak Ridge, TN). The electrochemical cell consisted of a working electrode (a polished GCE with immobilized $\mathrm{Cyt}_{3}$ ), an auxiliary electrode (platinum wire), and a reference saturated calomel electrode (SCE). Potential values with respect to the normal hydrogen electrode can be obtained by adding $240 \mathrm{mV}$. Measurements were done in $20 \mathrm{ml}$ of trishydroxymethyl aminomethane (Tris- $\mathrm{HCl}$ ) buffer (o.1 M, pH 7.6), deoxygenated under $\mathrm{N}_{2}$ atmosphere. All experiments were carried out at $25{ }^{\circ} \mathrm{C}$ under stirring conditions

\section{II.4. Biosensor characterization}

\section{II.4.1. Stability of the immobilized Cyt $c_{3}$}

Once the Cyt $c_{3}$ was immobilized on the GCE, cyclic voltametry was used to evaluate the stability of the immobilized protein.

\section{II.4.2. Characterization of the biosensors}

Chronoamperometry was used to determine biosensor characteristics (response time, calibration curve, sensitivity, specificity and detection range). Experiments were conducted at $-570 \mathrm{mV} / \mathrm{SCE}$ (the reduction potential of the enzyme) (Figure 2, black line), so that all of the 4 hemes except $\mathrm{Cr}(\mathrm{VI})$ were reduced at the electrode. When the potential was applied, a current was observed showing the reduction of Cyt $\mathrm{c}_{3}$ at the electrode. When the current had stabilized, indicating that the cytochrome was totally reduced, $\mathrm{Cr}(\mathrm{VI})$, As(V), As(III) or Fe(III) metal ions were added. The linear relationship between metal concentration $(x)$ and the intensity of the current produced ( $y$ ) was used ( $y=A x$ with $A$ being the sensitivity of the biosensor ( $\mathrm{nA} \mathrm{mg}^{-1}$ l or $\mathrm{nA} \mathrm{M}^{-1}$ )).

\section{II.5. Chemical reagents}

$\mathrm{Cr}$ (VI) (as $\mathrm{Na}_{2} \mathrm{CrO}_{4}$ ) and $\mathrm{As}\left(\mathrm{V}\right.$ ) (as $\mathrm{As}_{2} \mathrm{O}_{5}$ ) were dissolved in $\mathrm{H}_{2} \mathrm{O}$, As(III) (as $\mathrm{As}_{2} \mathrm{O}_{3}$ ) was dissolved in a $\mathrm{NaOH}$ solution, as described by (Battaglia-Brunet et al., 2002b.), and $\mathrm{Fe}(\mathrm{III})$ (as $\mathrm{FeCl}_{3}$ ) was dissolved in $15 \% \mathrm{HCl}$.

$\mathrm{Cr}(\mathrm{VI})$ was quantified using the Merck Spectroquant ${ }^{\circledR}$ kit 1.14758 .0001 based on the oxidation of diphenylcarbazide to the purple-colored $\mathrm{Cr}(\mathrm{III})$-diphenylcarbazone complex. $\mathrm{As}(\mathrm{V})$ and 
As(III) concentrations were determined as described by (Battaglia-Brunet et al., 2002b). Fe(III) was quantified using the Merck Spectroquant ${ }^{\circledR}$ kit 1.14761.0001.

\section{Results and discussion}

\section{III.1. Principle of the Cyt $\mathrm{c}_{3}$-based biosensor}

The Cyt $c_{3}$-based biosensor for $\mathrm{Cr}(\mathrm{VI})$ determination is based on the reduction of the metal by oxidation of the immobilized cytochrome that is electrochemically regenerated (Figure 1). The biosensor signal comes from the cytochrome regeneration current at an applied reduction potential when $\mathrm{Cr}(\mathrm{VI})$ is added to the solution. Electrons may be transferred directly from the electrode to the cytochrome in the working solution.

Chronoamperometry allows the current to be measured as a function of time, $I=f(t)$. When the current has stabilized for an applied potential, an increase in $\operatorname{Cr}(\mathrm{VI})$ concentration in the solution causes an increase in the current through the amperometric electrode. $\mathrm{Cr}$ (VI) can then be determined with a calibration curve of current change as a function of $\mathrm{Cr}(\mathrm{VI})$ concentration.

\section{III.2. Comparison of immobilization modes-characterization of the biosensors}

The first step in constructing a biosensor is determining how to immobilize the bioreceptor $\left(\right.$ Cyt $\mathrm{c}_{3}$ ) on the transducer GCE. We tested five immobilization modes: entrapment in PEDT, physical entrapment with a dialysis membrane, adsorption, adsorption+dialysis membrane and entrapment with a filter (Table 1). The ability of each mode to prevent Cyt $\mathrm{c}_{3}$ denaturation was studied using cyclic voltametry. The cyclic voltammograms obtained for all of these modes except PEDT entrapment were typical of Cyt $\mathrm{c}_{3}$ since the immobilized cytochrome was still a rapid and reversible system, and the redox potentials were characteristic of this cytochrome (Figure 2, black line). The catalytic wave observed in the presence of chromate demonstrates the ability of the immobilized enzyme to catalyze the reduction of chromate (Figure 2, grey line). Only in the case of entrapment in PEDT, therefore, does immobilization lead to protein denaturation and loss of $\mathrm{Cr}(\mathrm{VI})$-reductase activity.

Amperometric biosensors were therefore constructed with 'dialysis membrane', 'adsorption', 'adsorption+dialysis membrane' and 'filter' immobilization techniques. Figure 3 shows the biosensor response achieved with one of these (the 'dialysis membrane' electrode). Its detection range, linear domain and sensitivity are given in Figure 4, and the characteristics of all of the biosensors are given in Table 1.

The very short response time (a few seconds) obtained with all of the cytochrome $c_{3}$-based biosensors is remarkable. This is much shorter than the response times obtained with other enzymatic sensors for metal measurement such as the urease-based biosensor, whose response time varies from 10 min to $1 \mathrm{~h}$ (Krawczynski vel Krawczyk et al., 2000).

Experiments with 'filter' immobilization showed that, of all the filters tested, only a $0.1 \mu \mathrm{M}$ pore size filter enabled the detection of $\mathrm{Cr}(\mathrm{VI})$, probably because filters with smaller pore sizes acted as insulators (Table 1). However, experiments with a $0.1 \mu \mathrm{m}$ pore size filter did not give reproducible results. This mode of $\mathrm{Cyt}_{\mathrm{t}} \mathrm{c}_{3}$ immobilization is therefore unsatisfactory for the development of a biosensor.

The 'adsorption' immobilization technique (Table 1 and Figure 5) had the highest sensitivity, possibly because the dialysis membrane and the filter act as physical barriers, reducing the rate of $\mathrm{Cr}(\mathrm{VI})$ ion diffusion from the bulk solution to the Cyt $\mathrm{c}_{3}$ layer. This might explain the difference in sensitivity observed between the two immobilization techniques using adsorption with and without the dialysis membrane (Table 1).

The 'adsorption' biosensors did not, however, have a detection range $\left(0.20-0.80 \mathrm{mg} \mathrm{l^{-1 }}\right.$ $\mathrm{Cr}(\mathrm{VI})$ ) as broad as that of the 'dialysis membrane' biosensors (0.20-6.84 $\mathrm{mg} \mathrm{l}^{-1} \mathrm{Cr}(\mathrm{VI})$ ). They are, therefore, of less interest (Table 1). While there was no difference in sensitivity between the 'dialysis membrane' and 'adsorption+dialysis membrane' modes (Figure 5), the 'adsorption+dialysis membrane' biosensor had a wider $\mathrm{Cr}(\mathrm{VI})$ detection range. 
The lowest detection limit of the 'adsorption+dialysis membrane' biosensor is $0.2 \mathrm{mg} \mathrm{l}^{-1}$, which is greater than the regulatory standard for $\mathrm{Cr}(\mathrm{VI})\left(0.05 \mathrm{mg}^{-1}\right)$. Efforts should therefore be made to decrease the detection limit of the Cyt $c_{3}$-based biosensor. This could be done by (1) testing other techniques that might produce better results than 'dialysis membrane' immobilization, (2) using mediators that optimize electron transfer, and/or (3) decreasing the signal/noise background ratio, in particular by improving the electrochemical device.

\section{III.3. Amount of enzyme}

Various Cyt c3 concentrations, ranging from 2.85 to $114 \mu \mathrm{M}$ in $2 \mu \mathrm{l}$, were used to test the different biosensor configurations (Table 1). We were not able to obtain good sensitivity and reproducible results with $2.85 \mu \mathrm{M}$ of Cyt c3 (S.D. \pm 4.1 , Table 1). The Cyt c3 concentration giving the best sensitivity was determined for each mode of immobilization (Figure 5).

For 'dialysis membrane' immobilizations, a concentration of $14.3 \mu \mathrm{M}(372 \mathrm{ng})$ of Cyt c3 was the lowest concentration that allowed the best sensitivity and a satisfactory detection range (Figure 5). This is a very small amount of enzyme and is, therefore, very interesting for the development of low-cost biosensors. The urea-sensitive enzymatic sensor constructed by (Krawczynski vel Krawczyk et al., 2000) for $\mathrm{Pb}^{2+}, \mathrm{Fe}^{2+}, \mathrm{Sn}^{2+}, \mathrm{Zn}^{2+}$ and $\mathrm{Hg}^{2+}$ requires 2.5$15 \mathrm{mg}$ of enzyme.

\section{III.4. Specificity for $\mathrm{Cr}(\mathrm{VI})$}

(Lojou et al., 1998) reported that cytochromes c3 can also reduce several other metals in addition to $\mathrm{Cr}(\mathrm{VI})$. Furthermore, (Assfalg et al., 2002) have demonstrated that the interaction between $\mathrm{Cr}(\mathrm{VI})$ and cytochromes $\mathrm{c}_{3}$ could be electrostatic since $\mathrm{CrO}_{4}{ }^{2-}$ ions interact with the protein's lysines (positively charged amino acids). Other heavy metals, in particular, negatively charged ions, could therefore interfere with $\mathrm{Cr}(\mathrm{VI})$ detection by Cyt $\mathrm{c}_{3}$-based sensors. We therefore studied the possible interference of one metal (Fe(III)) and two metalloids (As(V) and As(III)). In the presence of each of these three ions, as shown in Figure 6 for As(V), no signal was observed, which suggests that there was no electron transfer between the Cyt $c_{3}$-based sensors and these ions. Addition of $\mathrm{Cr}(\mathrm{VI})$ caused a response of the biosensor (Figure 6). This strongly indicates that the biosensor was still able to detect $\mathrm{Cr}(\mathrm{VI})$ with the same sensitivity as in the absence of $\mathrm{As}(\mathrm{V})$, As(III) or Fe(III). As(V), As(III) and $\mathrm{Fe}(\mathrm{III})$ do not, therefore, interfere in $\mathrm{Cr}(\mathrm{VI})$ detection in the concentration range studied here. However, other HMM must be tested, in particular, Mo, as (Turyan and Mandler, 1997) have reported that $\mathrm{MoO}_{4}{ }^{2-}$ interferes with $\mathrm{Cr}(\mathrm{VI})$ determination, probably because of its similar structure and size. If a given metal appears to interfere with $\operatorname{Cr}(\mathrm{VI})$ detection, selective complexing agents could be used for the determination of individual concentrations.

\section{III.5. Influence of Tris- $\mathrm{HCl}$ buffer concentration}

Tris-HCl buffer has often been used in electrochemical studies with Cyt c3 (Lojou et al., 1998) to provide an optimal $\mathrm{pH}$ value (7.6) for enzyme activity and an optimal ionic strength for electrons transfer between the electrode and the solution. The effect of the Tris-HCl buffer concentration on signal intensity was, therefore, studied by chronoamperometry. We found that the main characteristics (sensitivity and concentration range) of Cyt $c_{3}$-based biosensors were not affected by Tris concentration (Table 2). We therefore used the usual Tris concentration for electrochemical experiments with cytochromes $c_{3}$ ( $0.1 \mathrm{M}$, (Lojou et al., 1998) in this study.

\section{III.6. Loss of enzyme activity at high Cr(VI) concentrations}

There is no correlation between $\mathrm{Cr}(\mathrm{VI})$ concentration and signal intensity for high concentrations of chromate ( $>4.5 \mathrm{mg} \mathrm{l}^{-1} \mathrm{Cr}(\mathrm{VI})$ ) (Figure 3 ). This indicates the loss of enzyme activity. NMR experiments with cytochrome c7, a c3-type cytochrome, have shown that $\mathrm{Cr}(\mathrm{VI})$ reduction is due to (1) an interaction between $\mathrm{CrO}_{4}{ }^{2-}$ and some lysines located near heme IV, (2) an intramolecular electron transfer from all of the hemes to heme IV and (3) an electron transfer from heme IV to Cr(VI) (Assfalg et al., 2002). An accumulation of Cr(III) ions near heme IV (due to $\mathrm{Cr}(\mathrm{VI})$ reduction) might, therefore, prevent $\mathrm{Cr}(\mathrm{VI})$ access to the reduction 
site, decreasing the $\mathrm{Cr}(\mathrm{VI})$ reduction capacities of Cyt $\mathrm{c}_{3}$. In this case, the enzyme might be able to recover its activity and it would therefore be possible to regenerate the biosensor by eliminating $\mathrm{Cr}$ (III). Another explanation for the loss of enzyme activity could be that high $\mathrm{Cr}(\mathrm{VI})$ concentrations denature the enzyme. In this case, regeneration would not be possible. In our experiments with Cyt $\mathrm{c}_{3}$-based biosensors, no recovery of enzyme activity was observed after incubation of the biosensor in a Tris buffer solution or after application of a very negative potential $(-1000 \mathrm{mV} / \mathrm{SCE})$. This suggests a denaturation of the Cyt $\mathrm{c}_{3}$. However, this result should be confirmed with other regeneration techniques (such as $\mathrm{pH}$ variation, EDTA and thioacetamide in a Tris-HCl buffer, cysteine in a phosphate buffer, NaI and EDTA, NaI alone, and any other reagents that could complex Cr(III) (Krawczynski vel Krawczyk et al., 2000)).

\section{Conclusion}

Enzymatic sensors based on Cyt $\mathrm{c}_{3}$ immobilized with a dialysis membrane are suitable for the detection of $\mathrm{Cr}(\mathrm{VI})$ bioavailability using an amperometric method. The principal characteristics and main advantages of the Cyt $\mathrm{c}_{3}$-based biosensor developed in this study are: rapid $\mathrm{Cr}(\mathrm{VI})$ quantification (a few minutes), a detection range of $0.20-6.84 \mathrm{mg} \mathrm{l}^{-1}$, good

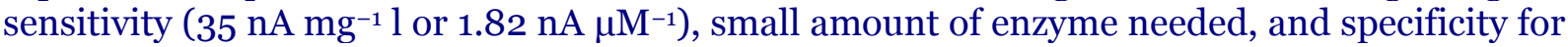
$\mathrm{Cr}(\mathrm{VI})$ (no detection of $\mathrm{As}(\mathrm{V})$, $\mathrm{As}(\mathrm{III})$ and $\mathrm{Fe}(\mathrm{III})$ ). Interference with other metals or metalloids should nevertheless be studied. Loss of enzyme activity at high $\operatorname{Cr}(\mathrm{VI})$ concentrations and sensor regeneration also require further investigation. Undeniably, cytochromes $c_{3}$ isolated from sulfate-reducing bacteria are attractive enzymes for the development of biosensors for $\mathrm{Cr}(\mathrm{VI})$ quantification because of their selective $\mathrm{Cr}(\mathrm{VI})$ reductase activity, chemical stability and high production rate in the bacterial cells.

\section{Acknowledgements}

This work was carried out under the European Commission's Fifth Framework Programme, Contract no EVK1-CT 1999-00033, project METALBIOREDUCTION. It also received financial support from the BRGM Research Directorate, who authorized the publication of this paper under reference No. 02496.

\section{References}

M. Assfalg, I. Bertini, M. Bruschi, C. Michel and P. Turano, The metal reductase activity of some multiheme cytochromes c: NMR structural characterization of the reduction of chromium (VI) to chromium (III) by cytochrome c(7). Proc. Natl. Acad. Sci. USA 99 (2002), pp. 9750-9754.

F. Battaglia-Brunet, S. Foucher, A. Denamur, I. Ignatiadis, C. Michel and D. Morin, Reduction of chromate by fixed films of sulfate-reducing bacteria using hydrogen as an electron source. J. Ind. Microbiol. Biotechnol. 28 (2002), pp. 154-159.

F. Battaglia-Brunet, M.-C. Dictor, F. Garrido, C. Crouzet, D. Morin, K. Dekeyser, M. Clarens and P. Baranger, An arsenic(III)-oxidizing bacterial population: selection, characterization, and performance in reactors. J. Appl. Microbiol. 93 (2002), pp. 656667.

P. Bianco, J. Haladjian and M. Bruschi, An electrochemical study of the stability of cytochrome c3 from Desulfovibrio desulfuricans Norway strain. Bioelectrochem. Bioenerg. 15 (1986), pp. 57-66.

M. Bruschi, The primary structure of the tetrahaem cytochrome c3 from Desulfovibrio desulfuricans (strain Norway 4). Description of a new class of low-potential cytochrome c. Biochim. Biophys. Acta 671(1981), pp. 219-226.

M. Bruschi, C.E. Hatchikian, L.A. Golovleva and J. LeGall, Purification and characterization of cytochrome c3, ferredoxin, and rubredoxin isolated from Desulfovibrio desulfuricans Norway. J. Bacteriol. 129 (1977), pp. 30-38. 
J. Cai and M.S. Dubow, Use of a luminescent bacterial biosensor for biomonitoring and characterization of arsenic toxicity of chromated copper arsenate (CCA). Biodegradation 8 (1997), pp. 105-111.

C. Cervantes, J. Campos-Garcia, S. Devars, F. Gutiérrez-Corona, H. Loza-Tavera, J. TorresGuzman and R. Moreno-Sanchez, Interactions of chromium with microorganisms and plants. FEMS Microbiol. Rev. 25 (2001), pp. 335-347.

B. Chardin, A. Dolla, F. Chaspoul, M.L. Fardeau, P. Gallice and M. Bruschi, Bioremediation of chromate; thermodynamic analysis of the effects of $\mathrm{Cr}(\mathrm{VI})$ on sulfate-reducing bacteria. Appl. Microbiol. Biotechnol. 60 (2002), pp. 352-360.

S.F. D'Souza, Microbial biosensors. Biosens. Bioelectron. 16 (2001), pp. 337-353.

L. Florens, P. Bianco, J. Haladjian, M. Bruschi, I. Protasevich and A. Makarov, Thermal stability of the polyheme cytochrome c3 superfamily. FEBS Lett. 373 (1995), pp. 280284.

J. Fredrickson, H. Kostandarithes, S. Li, A. Plymale and M. Daly, Reduction of Fe(III), Cr(VI), $\mathrm{U}(\mathrm{VI})$, and $\mathrm{Tc}(\mathrm{VII})$ by Deinococcus radiodurans R1. Appl. Environ. Microbiol. 66 (2000), pp. 2006-2011.

J. Haladjian, P. Bianco, F. Nunzi and M. Bruschi, A permselective-membrane electrode for the electrochemical study of redox proteins. Application to cytochrome c552 from Thiobacillus ferrooxidans. Anal. Chim. Acta 289 (1994), pp. 15-20.

R. Haser, M. Pierrot, M. Frey, F. Payan, J.P. Astier, M. Bruschi and J. Le Gall, Structure and sequence of the multihaem cytochrome c3. Nature 282 (1979), pp. 806-810.

A. Ivask, M. Virta and A. Kahru, Construction and use of specific luminescent recombinant bacterial sensors for the assessment of bioavailable fraction of cadmium, zinc, mercury and chromium in the soil. Soil Biol. Biochem. 34 (2002), pp. 1439-1447

F. Kormos and A.N. Lengauer, Studies concerning the biomonitoring of the degree of environmental pollution using urea-sensitive enzymatic sensor. Lab. Robotics Automat. 12 (2000), pp. 27-30.

T. Krawczynski vel Krawczyk, M. Moszczynska and M. Trojanowicz, Inhibitive determination of mercury and other metal ions by potentiometric urea biosensor. Biosens. Bioelectron. 15 (2000), pp. 681-69

M. Lehmann, K. Riedel, K. Adler and G. Kunze, Amperometric measurement of copper ions with a deputy substrate using a novel Saccharomyces cerevisiae sensor. Biosens. Bioelectron. 15 3-4 (2000), pp. 211-219.

E. Lojou, P. Bianco and M. Bruschi, Kinetic studies on the electron transfer between bacterial c-type cytochromes and metal oxides. J. Electroanal. Chem. 452 (1998), pp. 167-177.

D.R. Lovley and E.J.P. Phillips, Reduction of chromate by Desulfovibrio vulgaris and its c3 cytochrome. Appl. Environ. Microbiol. 60 (1994), pp. 726-728.

Michel, M. Brugna, C. Aubert, A. Bernadac and M. Bruschi, Enzymatic reduction of chromate: comparative studies using sulfate-reducing bacteria. Key role of polyheme cytochromes c and hydrogenases. Appl. Microbiol. Biotechnol. 55 (2001), pp. 95-100.

N. Peitzsch, G. Eberz and D.H. Nies, Alcaligenes eutrophus as a bacterial chromate sensor. Appl. Environ. Microbiol. 64 (1998), pp. 453-458.

S. Ramanathan, W. Shi, B.P. Rosen and S. Daunert, Sensing antimonite and arsenite at the subattomole level with genetically engineered bioluminescent bacteria. Anal. Biochem. 69 (1997), pp. 3380-3384.

M. Rege, J. Petresen, D. Johnstone, C. Turick, D. Yonge and W. Appel, Bacterial reduction of hexavalent chromium by Enterobacter cloacae strain Ho1 grown on sucrose. Biotechnol. Lett. 19 (1997), pp. 691-694.

S. Tauriainen, M. Karp, W. Chang and M. Virta, Luminescent bacterial sensor for cadmium and lead. Biosens. Bioelectron. 13 (1998), pp. 931-938.

B. Tebo and A. Obraztsova, Sulfate-reducing bacterium grows with $\mathrm{Cr}(\mathrm{VI}), \mathrm{U}(\mathrm{VI}), \mathrm{Mn}(\mathrm{IV})$ and Fe(III) as electron acceptors. FEMS Microbiol. Lett. 162 (1998), pp. 193-198.

I. Turyan and D. Mandler, Selective determination of $\mathrm{Cr}(\mathrm{VI})$ by a self-assembled monolayerbased electrode. Anal. Chem. 69 (1997), pp. 894-897. 
Biosensors and Bioelectronics, 2003, 19(4), 345-352, doi:10.1016/So956-5663(03)00191-X

P. Vignais, B. Billoud and J. Meyer, Classification and phylogeny of hydrogenases. FEMS Microbiol. Rev. 25 (2001), pp. 455-501.

\section{Figures}
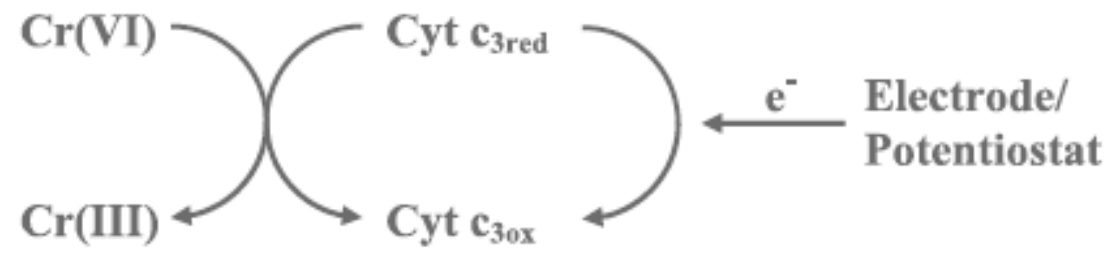

\section{Cr(VI) reduction}

\section{Electrochemical regeneration of Cyt $\mathbf{c}_{3 \text { red }}$}

Figure 1: Principle of Cyt $c_{3}$-based biosensor recognition of $\mathrm{Cr}(\mathrm{VI})$ : the Cyt $c_{3 r e d}$ regeneration current is proportional to the Cyt $c_{3 o x}$ content and therefore to the Cr(VI) content. The measured signal corresponds to the intensity of the regeneration current.

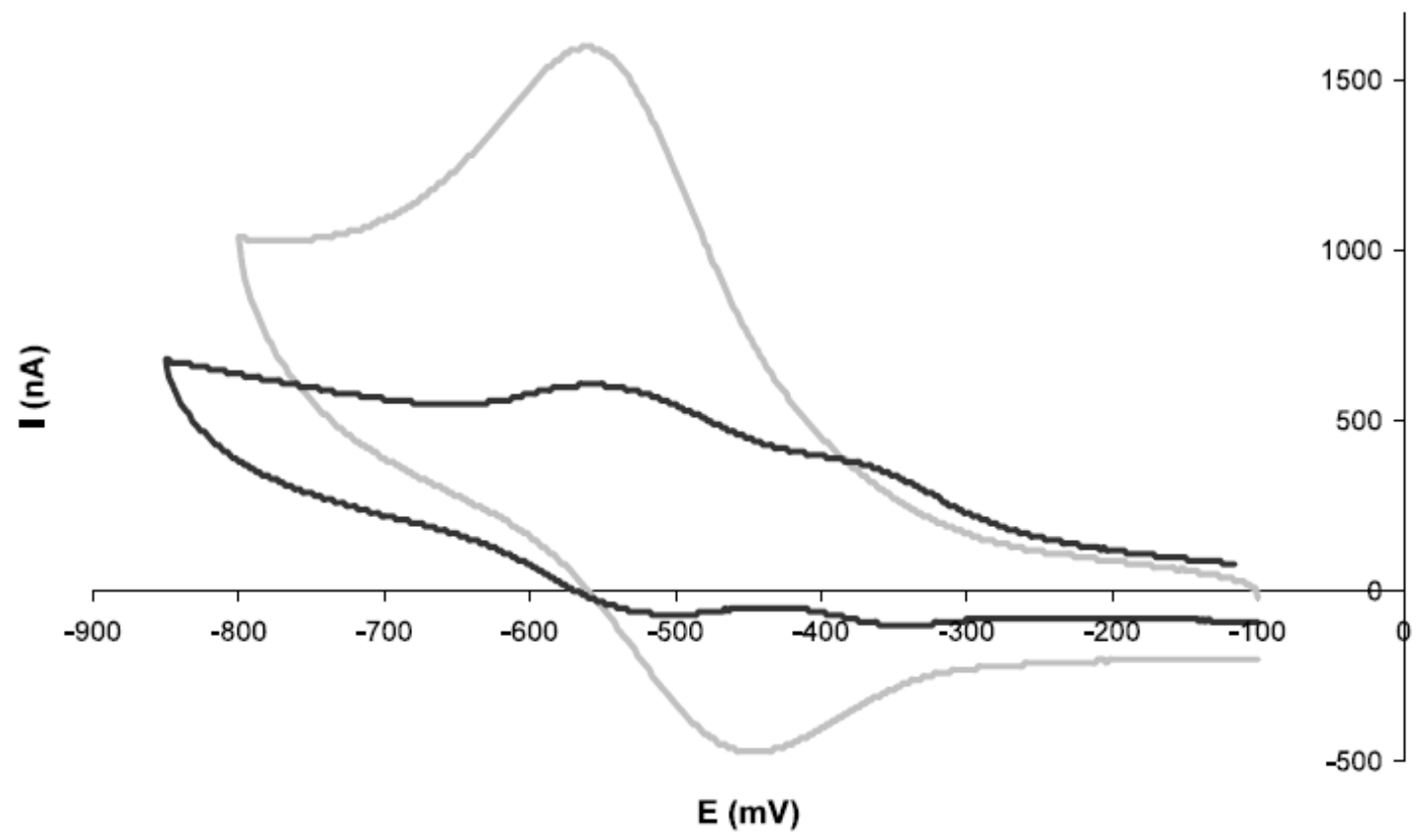

Figure 2: Cyclic voltammograms of the Cyt $c_{3}$-based biosensor in the absence (black line) and in the presence (grey line) of $\mathrm{Cr}(\mathrm{VI})\left(8.3 \mathrm{mg} \mathrm{l}^{-1}\right)$. Cyt $c_{3}$ was entrapped between a dialysis membrane and GCE. Scan rate: $20 \mathrm{mV}$ $s^{-1}$. 


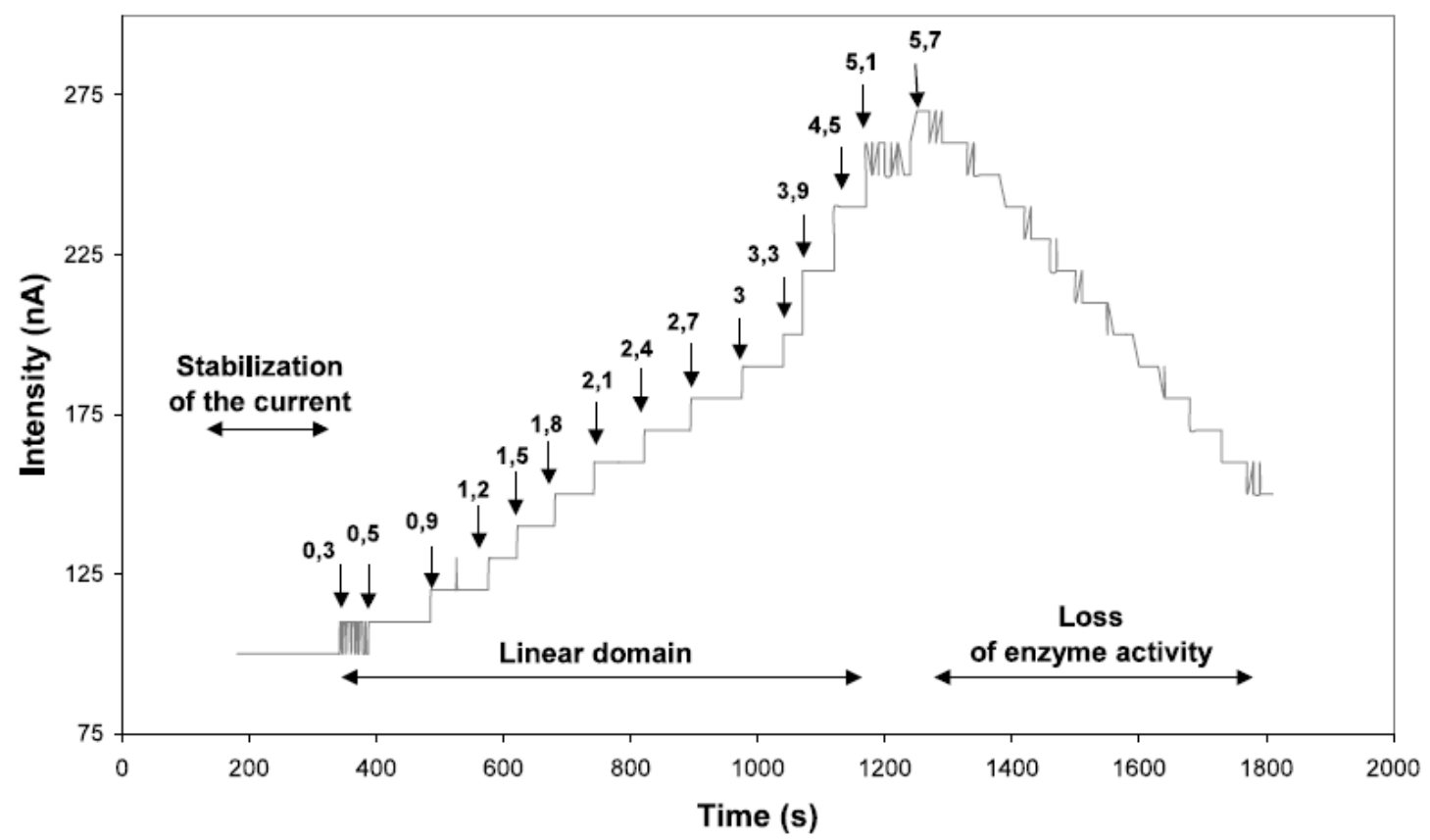

Figure 3: Chronoamperometry experiments showing the response of a Cyt $c_{3}$-based biosensor ( $47.5 \mu M$ Cyt $_{3}$ entrapped with a dialysis membrane electrode) to $\mathrm{Cr}(V I)$ concentration changes. Variation of the current was recorded at $-570 \mathrm{mV}$ (the reduction potential of the enzyme). Arrows indicate chromate addition (milligram per liter).

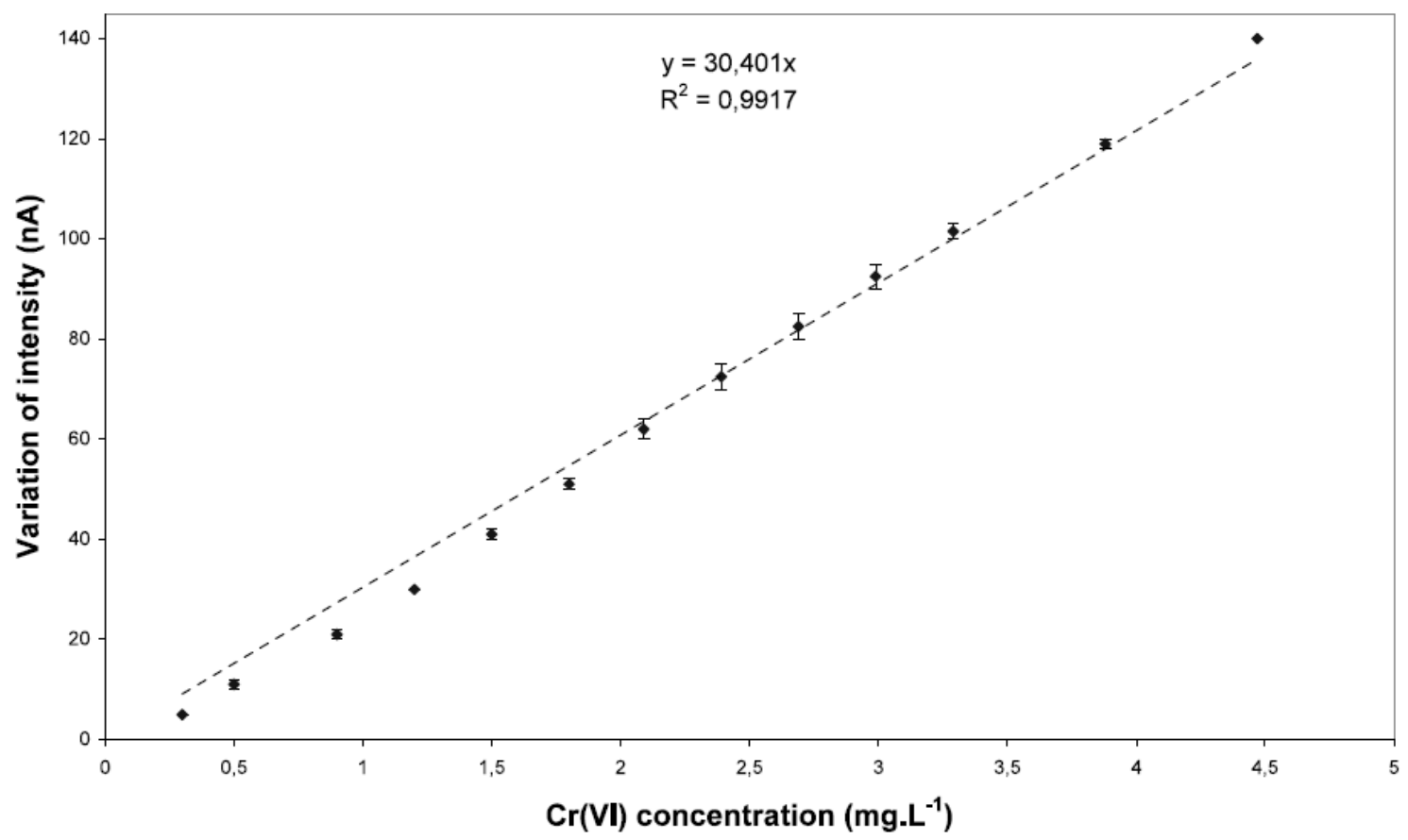

Figure 4: Calibration curve for a Cyt $c_{3}$-based biosensor ( $47.5 \mu \mathrm{M}$ Cyt $c_{3}$ entrapped within a dialysis membrane electrode). The curve was obtained from the linear domain of the chronoamperometry experiments in Figure $3 . A$ linear expression was calculated and the sensitivity determined for this biosensor was $30.40 \mathrm{nA} \mathrm{mg}{ }^{-1} l$. 


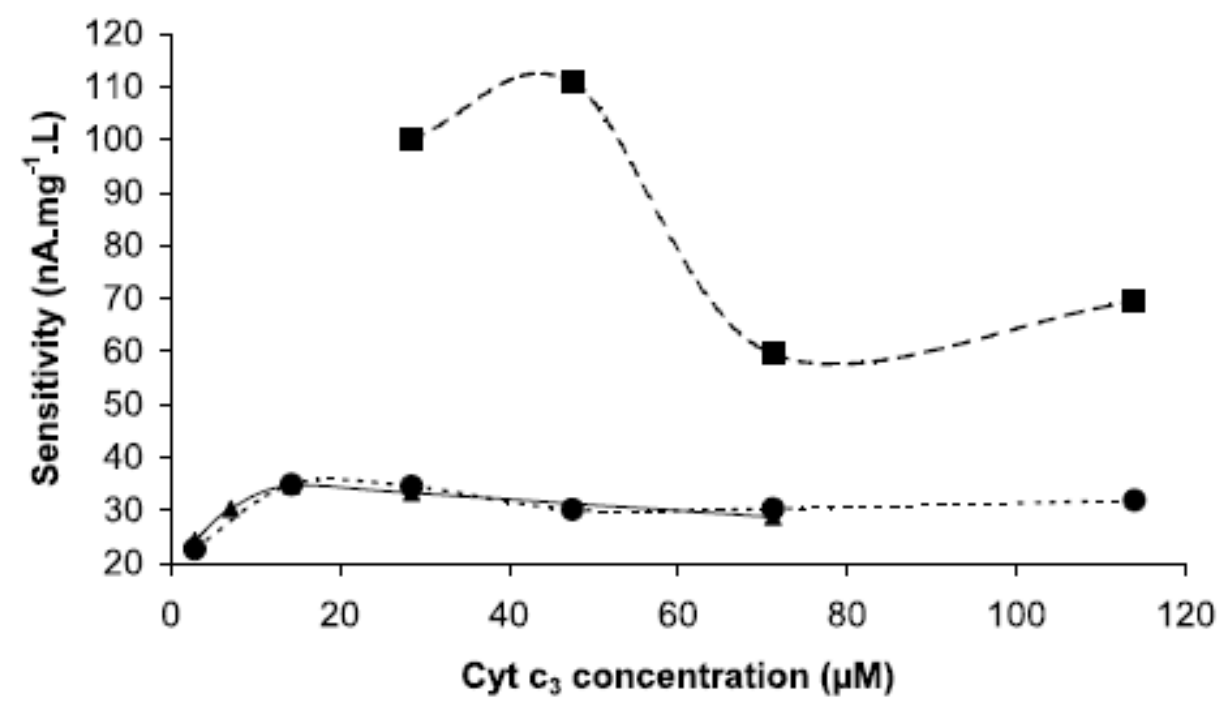

Figure 5: Sensitivity of biosensors as a function of Cyt $c_{3}$ concentration and various types of Cyt $c_{3}$ immobilization techniques: dialysis membrane $(\bullet)$, adsorption $(\bullet)$ and adsorption+dialysis membrane $(\bullet)$.

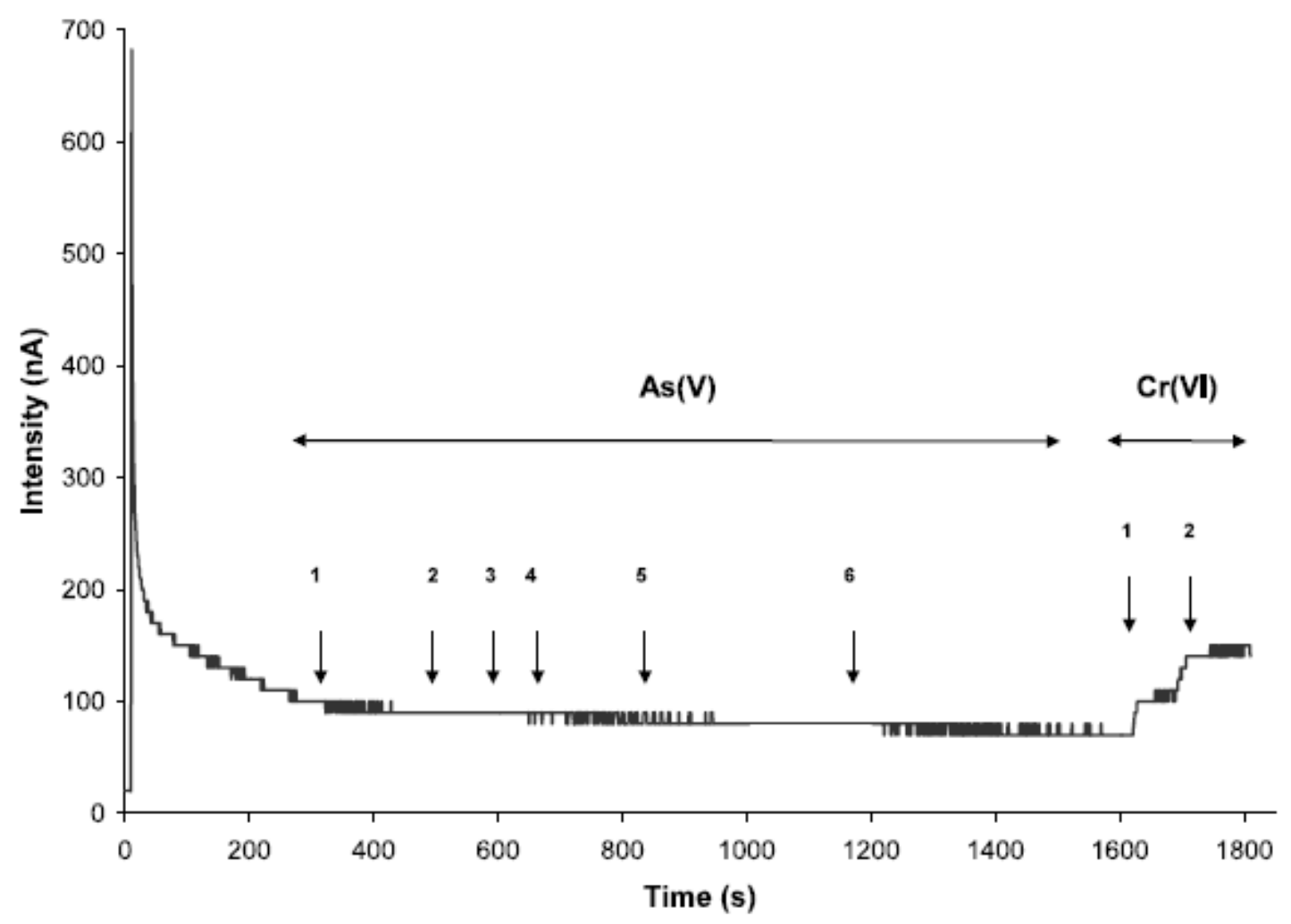

Figure 6: Specificity test. Chronoamperometry experiments with $71.25 \mu M$ Cyt $c_{3}$ entrapped with a dialysis membrane electrode. Variation of the current was recorded at $-570 \mathrm{mV} / \mathrm{SCE}$. Values above the vertical arrows indicate $\mathrm{As}(\mathrm{V})$ and $\mathrm{Cr}(\mathrm{VI})$ concentrations $\left(\mathrm{mg} \mathrm{l}^{-1}\right)$. 
Biosensors and Bioelectronics, 2003, 19(4), 345-352, doi:10.1016/S0956-5663(03)00191-X

Tables

Table 1: Characteristics of biosensors according to Cyt $c_{3}$ immobilization techniques

\begin{tabular}{|c|c|c|c|c|c|}
\hline $\begin{array}{l}\text { Immobilization } \\
\text { technique }\end{array}$ & {$\left[\right.$ Cyt $\left.c_{3}\right](\mu M)$} & Cyt $c_{3}$ stability & $\begin{array}{l}\text { Sensitivity (nA } \\
\left.m^{-1} l\right)\end{array}$ & $\begin{array}{l}\text { Detection } \\
\text { range }\left(\mathrm{mg} \mathrm{l}^{-1}\right)\end{array}$ & $\begin{array}{l}\text { Response } \\
\text { time (s) }\end{array}$ \\
\hline \multicolumn{6}{|l|}{ PEDT } \\
\hline & $14-114$ & No & $a$ & $b$ & $b$ \\
\hline \multicolumn{6}{|c|}{ Dialysis membrane } \\
\hline & 2.85 & Yes & 22.70 & $0.28-3.86$ & $O-5$ \\
\hline & 14.3 & Yes & 34.90 & $0.28-3.74$ & $O-5$ \\
\hline & 28.5 & Yes & 34.50 & $0.28-3.74$ & $O-5$ \\
\hline & 47.5 & Yes & $30.20 \pm 0.21$ & $0.30-4.47$ & $O-5$ \\
\hline & 71.25 & Yes & 30.30 & $0.20-4.38$ & $O-5$ \\
\hline & 114 & Yes & $31.90 \pm 2.62$ & $0.20-4.47$ & $O-5$ \\
\hline \multicolumn{6}{|l|}{ Adsorption } \\
\hline & 28.5 & Yes & 100 & $0.20-0.40$ & $O-5$ \\
\hline & 47.5 & Yes & 110.70 & $0.20-0.60$ & $O-5$ \\
\hline & 71.25 & Yes & 59.50 & $0.20-0.80$ & $O-5$ \\
\hline & 114 & Yes & $69.50 \pm 0.52$ & $0.20-0.80$ & $O-5$ \\
\hline \multicolumn{6}{|c|}{ Filter $(0.01 \mu M)$} \\
\hline & 60 & Yes & $b$ & $b$ & $b$ \\
\hline \multicolumn{6}{|c|}{ Filter $(0.05 \mu M)$} \\
\hline & 60 & Yes & $b$ & $b$ & $b$ \\
\hline \multicolumn{6}{|c|}{ Filter $(0.1 \mu M)$} \\
\hline & 60 & Yes & $c$ & $0.35-1.60$ & $O-5$ \\
\hline \multicolumn{6}{|c|}{ Adsorption + dialysis membrane } \\
\hline & 2.85 & Yes & $24.30 \pm 4.10$ & $0.28-5.17$ & $O-5$ \\
\hline & 7.1 & Yes & 30.30 & $0.20-4.18$ & $O-5$ \\
\hline & 14.3 & Yes & $34.70 \pm 0.60$ & $0.40-5.56$ & $O-5$ \\
\hline & 28.5 & Yes & 33.30 & $0.80-6.35$ & $O-5$ \\
\hline & 71.25 & Yes & 28.70 & $0.90-6.84$ & $O-5$ \\
\hline
\end{tabular}

Experiments were performed in a Tris/HCl buffer (o.1 M, pH 7.6).

${ }^{a}$ No S.D. means that the experiment was unique.

${ }^{b}$ No result could be obtained.

${ }^{c}$ Non reproducible experiment.

Table 2: Influence of Tris concentration ( $p H$ 7.6) on biosensor properties (Cyt $c_{3}(71.25 \mu M)$ immobilized with a dialysis membrane)

\begin{tabular}{|l|l|l|l|}
\hline Tris buffer $\mathrm{pH} 7.6(\mathrm{M})$ & Sensitivity $\left(\mathrm{nA} \mathrm{mg}^{-1} \mathrm{l}\right)$ & Detection range $\left(\mathrm{mg} \mathrm{l}^{-1}\right)$ & Response time (s) \\
\hline 0.05 & 25.13 & $0.20-5.96$ & $0-5$ \\
\hline 0.1 & 30.0 & $0.20-4.38$ & $0-5$ \\
\hline 0.2 & 32.75 & $0.20-4.77$ & $0-5$ \\
\hline 0.5 & 24.60 & $0.80-5.56$ & $0-5$ \\
\hline
\end{tabular}

